\title{
FEDERAL COLLECTIVE BARGAINING AFTER ELECTROLUX
}

\author{
Jason Harris*
}

\section{INTRODUCTION}

The Workplace Relations Act 1996 (Cth) ('the Act') pt VIB establishes a framework for the registration and enforcement of certified agreements, which are collective industrial instruments that regulate the employment relationship for a significant proportion of the workforce. ${ }^{1}$ The Act provides for agreements between unions of employees and employers and agreements between employers and employees directly. ${ }^{2}$ A certified agreement comes into effect only after it is approved by the employer and a 'valid majority' of its employees ${ }^{3}$ and is registered by the Australian Industrial Relations Commission ('the Commission'). ${ }^{4}$ The significance of registration of a certified

* Jason Harris, BA LLB (UWS), Lecturer, School of Business Law and Taxation, UNSW. The writer would like to thank Professor Phillipa Weeks and Mr John Trew QC, as well as the two anonymous referees for their helpful comments. An earlier version of this article was presented at the ALTA 2005 Annual Conference and the writer would also like to thank the participants of the conference for their helpful comments. All errors remain the sole responsibility of the writer. Lastly, the writer would like to thank the editors of the Federal Law Review for their patience and support during the revisions of this article at a time of great upheaval in industrial law in Australia.

1 Recent Australian Bureau of Statistics figures indicate that collective industrial agreements, such as certified agreements, regulate terms and conditions of approximately 41 per cent of the Australian workforce: Australian Bureau of Statistics, 'Methods of Setting Pay' (2003) 6105.0 Australian Labour Market Statistics 26.

2 Workplace Relations Act 1996 (Cth) ss 170LJ, 170LK. The Act also provides for certified agreements between employers and unions in settlement of an industrial dispute: Workplace Relations Act 1996 (Cth) pt IVB, div 3. There are also greenfields agreements where employees have not yet been engaged on a new worksite: Workplace Relations Act 1996 (Cth) s 170LL. The Workplace Relations Amendment (Work Choices) Act 2005 (Cth) will retain these agreements: see ss 96A (employee/employer collective agreements), 96B (employer/union collective agreements), 96C (union greenfields agreements). There is also a new non-union greenfields agreement: s 96D.

$3 \quad$ Workplace Relations Act 1996 (Cth) ss 170LE, 170LJ(2), 170LK(1). The Act defines a 'valid majority' as a majority of persons employed at a particular time whose employment is or will be subject to the agreement: Workplace Relations Act 1996 (Cth) s 170LE.

$4 \quad$ Workplace Relations Act 1996 (Cth) ss 170LT(5), 170LX. The Workplace Relations Amendment (Work Choices) Act 2005 (Cth) provides for agreements to take effect once they are lodged with the Office of Employment Advocate, rather than requiring the parties to register the agreement with the Commission, which the current law requires: see new pt VB, div 5, s 100. 
agreement lies in the imposition of legally enforceable rights and obligations upon the parties bound by the agreement. One of the most significant obligations imposed on the parties bound by a registered certified agreement is the obligation not to engage in industrial action for the duration of the agreement, which is ordinarily no longer than three years. ${ }^{5}$

While industrial action may not be lawfully undertaken by the parties during the term of the certified agreement, ${ }^{6}$ the Act does allow industrial action to be taken after the nominal expiry of the certified agreement, ${ }^{7}$ provided that the parties are negotiating a new agreement during a bargaining period. ${ }^{8}$ Industrial action will only be permitted if it is taken for the purpose of 'supporting or advancing claims made in respect of the proposed agreement'. ${ }^{9}$ Until recently, it was commonly thought that the reference to the 'proposed agreement' in this context was simply to the proposed certified agreement that the parties were negotiating. The proposed agreement must be precisely identified because it is only industrial action taken in support of that agreement that gains the protection of the Act.

It is important to note that not all agreements negotiated between the parties are capable of being certified by the Commission. Section 170LI of the Act provides that an agreement may only be submitted for certification by the Commission if it is 'about matters pertaining to the relationship between' employers and their employees. ${ }^{10}$ The issue concerning whether or not a particular matter pertains to the employment

$5 \quad$ Workplace Relations Act 1996 (Cth) ss 170MC, 170MN. The Workplace Relations Amendment (Work Choices) Act 2005 (Cth) allows certified agreements to last for no more than five years, although greenfields agreements will only be permitted to last for one year: s 101 .

$6 \quad$ Workplace Relations Act 1996 (Cth) s 170MN. The Workplace Relations Amendment (Work Choices) Act 2005 (Cth) contains the same prohibition: ss 108E, 110.

$7 \quad$ Workplace Relations Act 1996 (Cth) ss 170LX(2), 170MN, 170ML. The Workplace Relations Amendment (Work Choices) Act 2005 (Cth) contains a similar provision: s 108.

8 Either party to the agreement may initiate a bargaining period by giving notice to the other party: Workplace Relations Act 1996 (Cth) ss 170MI-170MK. The Workplace Relations Amendment (Work Choices) Act 2005 (Cth) contains a similar provision: s 107.

9 Workplace Relations Act 1996 (Cth) s 170ML(2). For a detailed discussion of the procedures involved in taking protected industrial action see Greg McCarry, 'Industrial Action Under the Workplace Relations Act 1996 (Cth)' (1997) 10 Australian Journal of Labour Law 133; Victor Di Felice, 'Stopping or Preventing Industrial Action in Australia' (2000) 24 Melbourne University Law Review 310; Breen Creighton and Andrew Stewart, Labour Law (4th ${ }^{\text {th }}$ ed, 2005) ch 18. The Workplace Relations Amendment (Work Choices) Act 2005 (Cth) maintains this position: s 108(2), 108(3).

10 See further Creighton and Stewart, above n 9, ch 4. The Workplace Relations Amendment (Work Choices) Act 2005 (Cth) represents a change in the constitutional basis of the Workplace Relations Act 1996 (Cth), from the conciliation and arbitration power (s 51(xxxv) of the Constitution) to the corporations power (s 51(xx) of the Constitution). There is therefore no similar requirement that agreement be about matters pertaining to the employment relationship, as this phrase was a requirement of the regulation of industrial disputes that was necessary to bring the law within the conciliation and arbitration power. The new use of the corporations power means that the requirement of interstate labour disputes is no longer needed. However, the limitations imposed by the current s 170LI appear to be repeated under the new concept of 'prohibited content', which is dealt with in more detail in the Postscript below. 
relationship has been a long standing feature of Australian industrial relations law because of its connection with the meaning of an industrial dispute under the award system. For much of the last 100 years Australian industrial relations laws have been based on the settlement of industrial disputes through the use of compulsory arbitration in the form of award-making by the Commission and its predecessors. The concept of an industrial dispute was itself based on, inter alia, the requirement that the dispute be about matters pertaining to the relationship between employers and employees. ${ }^{11}$ Unfortunately, the High Court of Australia has been unable to develop a clear and consistent interpretation of what matters may or may not pertain to the relationship between employers and employees. Early decisions defined the concept of matters pertaining to the employment relationship relatively broadly. However, in later decisions a more restrictive approach was adopted..$^{12}$ The prevailing view seems to accept that a matter does not pertain to the employment relationship merely because it involves employers and employees. Rather, the matter must relate to the employer and employee in their capacity as such. ${ }^{13}$ For example, the provision of superannuation is a matter pertaining to the employment relationship because it forms part of the remuneration for the work performed and therefore impacts on the parties because of their employment status. ${ }^{14}$ However, while an employee may have a dispute with their employer because of the employer's social or political views, such a dispute is not of itself a matter pertaining to the employment relationship, because it does not arise because of the employment status, but rather because of the nature of the social or political view held. ${ }^{15}$

Until recently there has been considerable confusion about whether each individual clause in a proposed certified agreement must satisfy the s 170LI requirements, or rather, whether the proposed agreement should be characterised as a whole. ${ }^{16}$ The High Court's majority decision in Electrolux Home Products Pty Ltd v Australian Workers' Union ${ }^{17}$ has found that an agreement cannot be characterised as a 'proposed agreement' for the purposes of taking protected industrial action if it contains substantive clauses that do not pertain to the relationship between the employer and its employees. This therefore requires that the proposed agreement between the parties

11 The Industrial Relations Act 1988 (Cth) s 4(1) defined an industrial dispute by reference to matters pertaining to the relationship between employers and employees, while its predecessor the Conciliation and Arbitration Act 1904 (Cth) s 4(1) defined an industrial dispute by reference to industrial matters, which were themselves defined by reference to 'all matters pertaining to the relations of employers and employees'.

12 Creighton and Stewart, above $\mathrm{n} 9,[4.26]-[4.32]$.

13 R v Kelly; Ex parte Victoria (1950) 81 CLR 64, 84.

14 Re Manufacturing Grocers Employees Federation of Australia (1986) 160 CLR 341.

15 R v Coldham; Ex parte Fitzsimmons (1976) 137 CLR 153, 163 (Stephen J).

16 Compare Re Atlas Steels Metals Distribution Certified Agreement 2001-2003 (2002) 114 IR 62 ('Re Atlas Steels') and Electrolux Home Products Pty Ltd $v$ Australian Workers Union [2001] FCA 1600 ('Electrolux (FCA Merkel J)') with Automotive, Food, Metals, Engineering, Printing and Kindred Industries Union v Electrolux Home Products Pty Ltd (2002) 118 FCR 177 ('Electrolux (FCFC)') and Automotive, Food, Metals, Engineering, Printing and Kindred Industries Union v Unilever Australia Ltd (2003) 132 IR 34 ('Unilever'). See also Leigh Johns, 'To Certify or Not to Certify? - That is (Still) the Question' (2003) 16 Australian Journal of Labour Law 108.

17 (2004) 209 ALR 116 ('Electrolux'). 
be assessed clause by clause to determine if there are any clauses that do not pertain to the employment relationship.

This article will consider the High Court's reasoning in the Electrolux case and the legal and practical consequences that flow from the decision. It will be argued that the majority decision unfortunately adopted a narrow construction of the Act that will cause, and indeed is already causing, substantial difficulties and uncertainty about the process of federal collective bargaining in Australia. It is submitted that the result of this decision is a federal collective bargaining regime that is less efficient and more complex than necessary. Furthermore, it will be argued that the effect of the decision is to impose unrealistic demands on parties to certified agreements in a manner that unreasonably interferes with the balance of power in collective bargaining negotiations. Lastly, this article will evaluate the possible options for collective bargaining that lie outside of the formal certification process in the Act.

In order to fully appreciate the significance of the Electrolux decision it is appropriate to first consider the scope of the legal rights to take industrial action which have been limited by the ruling.

\section{A The importance of industrial action}

While the Act provides the framework for registering a collective agreement assented to by an employer and its employees, the Act does not provide a comprehensive code about how these agreements are to be reached. The actual process of reaching a collective agreement is left largely to the parties to determine. ${ }^{18}$ This is consistent with the statutory objects provided in the Act, which relevantly state that the purpose of the Act is to provide a framework for promoting the determination of employment terms and conditions at the enterprise level, with employers and employees permitted to reach an agreement that is most suitable to them regardless of whether or not that agreement is provided for in the Act. ${ }^{19}$ Therefore, it can be said that Australia's federal collective bargaining regime provides for the parties to determine the workplace terms and conditions governing their employment relationship without third party interference. This also means that disputes about the form and content of any agreement must generally be resolved by the parties themselves at the enterprise level. $^{20}$

18 One of the features of the recent Workplace Relations Amendment (Work Choices) Act 2005 (Cth) has been to increase attention on alternative dispute resolution between employers and employees/unions: see the newly inserted Workplace Relations Act 1996 (Cth) pt VIIA.

19 Workplace Relations Act 1996 (Cth) ss 3(b), 3(c). The Workplace Relations Amendment (Work Choices) Act 2005 (Cth) replaces these provisions with similarly worded goals: ss 3(d), 3(e).

20 The Commission is generally prohibited from exercising its arbitration powers during a bargaining period: Workplace Relations Act 1996 (Cth), s 170N. Under the amendments brought in by the Workplace Relations Amendment (Work Choices) Act 2005 (Cth), the Commission will primarily have a conciliatory role in relation to industrial disputes. 
It is submitted that the ability to take industrial action ${ }^{21}$ is integral to the fair operation of the process of collective bargaining at the federal level. In the absence of a mechanism for compulsory dispute resolution the parties are left with using their own level of bargaining power as a lever to attempt resolution of the dispute about the nature and contents of the proposed agreement. The ability to take industrial action to further one's own claims for the content of a certified agreement is an important tool in providing a balance between the bargaining power of employers and employees. ${ }^{22}$ As one commentator puts it, 'the power to bargain collectively is underpinned by the right to strike of employees. ${ }^{23}$ Where one of the parties has little or no bargaining power, the collective bargaining process becomes inevitably a unilateral imposition of workplace terms and conditions.

\section{B 'Protected industrial action'}

Ordinarily, industrial action will constitute a breach of contract. ${ }^{24}$ Certain types of industrial action (such as picketing) may also breach other laws such as the tort of interference with contractual relations. ${ }^{25}$ There is also a range of statutory powers and penalties that may be used where industrial action is undertaken without the protection of the Act. ${ }^{26}$ One of the key features of the system of federal collective bargaining is the ability to take industrial action without fear of legal action by the other party ('protected industrial action'). ${ }^{27}$ Industrial action will only be protected from legal action if it:

- is taken for the purpose of supporting or advancing claims in the proposed agreement;

- occurs after three days notice has been provided by the party engaging in industrial action; ${ }^{28}$ and

- occurs during a bargaining period.

Protected industrial action cannot be taken before the nominal expiry date of the current certified agreement. ${ }^{29}$

21 Industrial action is defined broadly in the Workplace Relations Act 1996 (Cth) s 4, to include work bans or limitations, or the performance of work in a manner different from that in which it is customarily performed. This definition also appears in the Workplace Relations Amendment (Work Choices) Act 2005 (Cth) s 106A.

22 Paul Davies and Mark Freedland, Kahn-Freund's Labour and the Law (3rd ed, 1983) 291-3.

23 Steven Anderman, Labour Law: Management Decisions and Workers' Rights (2nd ed, 1993) 73.

24 Creighton and Stewart, above n 9, [18.59]-[18.61].

25 Ibid [18.66]-[18.83].

26 See Workplace Relations Act 1996 (Cth) ss 127, 170NC; Creighton and Stewart, above n 9, ch 18; McCarry, above n 9; Di Felice, above n 9. Similar powers have been introduced by the Workplace Relations Amendment (Work Choices) Act 2005 (Cth): ss 104, 111, 111A.

27 Workplace Relations Act 1996 (Cth) ss 170ML, 170MU. See further McCarry, above n 9. The Workplace Relations Amendment (Work Choices) Act 2005 (Cth) provides similar protection: ss 108, 108L, 108M.

28 Workplace Relations Act 1996 (Cth) s 170MO. The Workplace Relations Amendment (Work Choices) Act 2005 (Cth) has reproduced this requirement in s 108F.

29 Workplace Relations Act 1996 (Cth) s 170MN. The Workplace Relations Amendment (Work Choices) Act 2005 (Cth) contains a similar provision in s 108E. 
It can therefore be said that a feature of the federal system of collective bargaining is periods of industrial harmony during the life of an agreement followed by occasional industrial unrest whilst the parties flex their bargaining power in an attempt to persuade the other party to agree to their terms regarding the form and content of the next certified agreement. After an agreement is certified, the parties then settle into another period of industrial peace, because taking industrial action during the term of a certified agreement is unlawful. ${ }^{30}$

\section{THE UNCERTAINTY OF DIVERGING STATUTORY INTERPRETATIONS}

Industrial action usually has a significant impact on the parties involved in an industrial dispute, costing employers and employees lost productivity and money. It is therefore in the interests of all parties to a certified agreement that the ability to engage in and control industrial action during a bargaining period be as certain as possible. However, the last several years have been a time of considerable uncertainty concerning the scope of the certification process and, therefore, the ability to take protected industrial action under the Workplace Relations Act 1996 (Cth). During this time there has been a stark divergence between two lines of authority in the Federal Court of Australia and the Commission. ${ }^{31}$ These two lines of authority diverge on the basis of what method of statutory interpretation should be employed when considering the provisions relating to certified agreements and protected industrial action. This article will refer to the two competing approaches as 'the holistic approach' and 'the specific approach'. The various stages of the Electrolux litigation demonstrate each of these approaches and, therefore, before considering the details of the conflicting authorities, it is necessary to say something of the facts involved in Electrolux.

\section{A Facts in Electrolux ${ }^{32}$}

A number of unions had members employed by Electrolux, who were covered by a certified agreement with a nominal expiry date of 30 June 2001. During the period between April and September 2001 the unions and Electrolux attempted to form a new collective agreement. During the negotiations, Electrolux refused to formulate a new agreement with the unions on the basis of their request for the agreement to include:

1. worksite access for union shop stewards;

2. the establishment of a trust fund to ensure that employee entitlements could be met; and crucially

30 It is recognised that unlawful strikes have been a feature of industrial relations long before the creation of protected industrial action in 1993. However, these 'wildcat strikes' may be dealt with by obtaining an order from the Commission under the Workplace Relations Act 1996 (Cth) s 127. See further McCarry, above n 9; Di Felice, above n 9. The Workplace Relations Amendment (Work Choices) Act 2005 (Cth) has moved the Commission's powers against industrial action into pt VC, div 6.

31 See above $\mathrm{n} 16$.

32 This summary of the facts is based on an earlier article by the writer: see Jason Harris, 'The High Court Limits Protected Industrial Action' (2005) 57 Keeping Good Companies 42. 
3. a requirement that Electrolux charge each non-union member employee an annual bargaining fee of $\$ 500$ (which was greater than the price of union membership). ${ }^{33}$

When Electrolux refused to accept these demands the unions gave notice of their intention to take industrial action. The unions assumed that because the workers were engaging in industrial action to further their claims in negotiating a new certified agreement the action would be protected. The unions' characterisation of the protected status of the industrial action was principally based on two arguments. First, the unions argued that even if any of the three claims were not matters pertaining to the relationship between employers and employees that did not mean that their inclusion in the proposed certified agreement prevented the agreement as a whole being so characterised. Secondly, as the workers were genuinely engaging in industrial action to further their negotiations for a new collective bargaining agreement, the action must be protected under the Act.

Electrolux argued that the industrial action was not protected on the basis that the wording of s 170LI required every term of a proposed certified agreement to constitute a matter 'pertaining to the employment relationship'. If this argument were correct, then where the proposed agreement did contain a term not pertaining to the employment relationship, the parties could not take protected action during the negotiations for the proposed agreement. The reference to 'proposed agreement' in s 170ML could not be construed as intending to confer protected status to industrial action in relation to a proposed agreement that would not be capable of certification under the Act. This interpretation drew heavily on the wording of s 170LH which provides, inter alia, that s 170LI sets out requirements that must be satisfied for the certification of agreements between employees or organisations of employees and constitutional corporations. It is now appropriate to consider how these claims were dealt with by the court.

The unions were unsuccessful at trial with Merkel J finding that the bargaining fee clause did not pertain to the requisite relationship, ${ }^{34}$ which in his view prevented the proposed collective agreement from being certified because it did not meet the requirements of s 170LI. ${ }^{35}$ The consequence of this finding was that the industrial action taken by the unions and their members could not, in Merkel J's view, satisfy the requirements of s 170ML. ${ }^{36}$ On appeal, a Full Court of the Federal Court found that the mere fact that a proposed agreement contained some terms that did not pertain to the

33 It should be noted that prior to the High Court's decision the federal Parliament passed the Workplace Relations Amendment (Prohibition of Compulsory Union Fees) Act 2003 (Cth), which inserted s 298SA prohibiting unions from demanding a bargaining services fee outside of bargaining services contracts, and amended ss 170LU(2A) and 298Z(5)(b) to prevent the Commission from certifying an agreement that contains a bargaining services fee. These provisions have been retained in the freedom of association provisions under the renumbering done by the Workplace Relations Amendment (Work Choices) Act 2005 (Cth): see s 271(1)(e). Presumably the provision of a bargaining services fee will be prescribed as 'prohibited content' under the new ss 101D-101F.

34 Electrolux (FCA Merkel J) [2001] FCA 1600, [40]-[48].

35 Ibid [49]-[54].

36 Ibid [52]-[55]. 
employment relationship of the parties (in this case the union bargaining fee clause) did not prevent the agreement from being certified, provided that the agreement as a whole could be said to be about matters pertaining to the relationship between the employer and its employees. The Full Court therefore found that the unions' industrial action was protected. ${ }^{37}$ On appeal from the Full Court, a majority of the High Court (61) allowed the appeal and approved of Merkel J's reasoning on the requirements of $s$ $170 \mathrm{LI}$ and the consequent incapacity to take protected industrial action. ${ }^{38}$

It is now appropriate to consider the differences in interpretive approach as demonstrated in the Electrolux cases. It is submitted that the decisions by Merkel J at trial and the majority in the High Court on appeal may be classified as applying a highly narrow specific approach, while the Full Court of the Federal Court and Kirby J in dissent may be classified as applying a holistic approach. ${ }^{39}$

\section{B The holistic approach}

This line of authority assesses the agreement as a whole document, rather than requiring a specific analysis of each particular clause and is based on the perceived parliamentary intention of the legislative requirements for certification by the Commission (hereafter referred to as the 'holistic approach'). The holistic approach states that an agreement will be capable of certification provided that it can be characterised as a whole as being one that is 'about matters pertaining to the relationship between employers and employees'. That is, the holistic approach does not involve characterising each individual clause in a proposed agreement, but rather focuses on the general import of the agreement to assess compliance with s 170LI. The proponents of this approach draw support from the stated purposes of the Act, ${ }^{40}$ expressed with an appreciation of the history of Australian industrial relations, particularly ambit claims and paper disputes. This construction therefore allows the parties greater scope to take protected industrial action because the range of agreements that may support such action will be broader than if the alternative interpretation is adopted. It is submitted that this result also provides for a fairer federal collective bargaining regime.

The holistic approach is exemplified by the decision of the Full Bench of the Commission in Automotive, Food, Metals, Engineering, Printing and Kindred Industries Union $v$ Unilever Australia Ltd. ${ }^{41}$ In that case the Full Bench gave a lengthy judgment that sought to provide guidance on what it saw as the proper approach to interpreting s 170LI. The Full Bench stated that s 170LI describes

an agreement about the relationship between real people, in actual work locations. It is necessary to ask rhetorically, why it is open, let alone necessary, to import into that description an added conceptual notion to justify a clause by clause analysis of the terms agreed for pertinence, to the relationship; or, (the expected answer may be more

$37 \quad$ Electrolux (FCFC) (2002) 118 FCR 177

38 Electrolux (2004) 209 ALR 116.

39 As to the broad/narrow approaches to interpretation taken by the Federal Court in relation to outsourcing and transmission of business provisions, see Jason Harris, 'More Uncertainty for Outsourcing Arrangements' (2004) 56 Keeping Good Companies 36.

40 Workplace Relations Act 1996 (Cth) s 3.

41 (2003) 132 IR 34 ('Unilever'). 
hesitant), a notional abstraction of the reference relationship, to make it between the persons, as employer, and as employee ${ }^{42}$

This passage indicates that in the view of the Full Bench in Unilever, the purpose underpinning the legislation (ie, flexibility in negotiating and agreeing on appropriate workplace terms and conditions) would be frustrated if the legislation imposed on employees the requirement to engage in a technical, legalistic process of definitively characterising each individual clause in the proposed agreement.

The holistic approach has also been endorsed by obiter comments in the Full Court of the Federal Court decision in Automotive, Food, Metals, Engineering, Printing and Kindred Industries Union v Electrolux Home Products Pty Ltd, 43 which has since been overturned on appeal. In that case, the Full Court stated that an agreement should be characterised as a whole, rather than individually characterising each clause to see if it, as opposed to the whole of the agreement, pertained to the relationship between employers and employees. ${ }^{44}$ This approach was based on the phrase 'about matters pertaining...', which in the view of the Full Court meant that the agreement as a whole needed to be tested for compliance with s $170 \mathrm{LI} .{ }^{45}$ In the Full Court's view, a certified agreement could still be said to be about matters pertaining to the relevant relationship even where it contained one or more clauses that in themselves did not pertain to that relationship. ${ }^{46}$ The Full Court was of the view that this interpretation fit within the stated purposes of the Act, to provide maximum choice and flexibility for workplace terms and conditions to be determined at the enterprise level, even if not formally provided for by the Act. ${ }^{47}$

\section{The specific approach}

The specific approach to interpreting the requirements for certification in pt VIB, and therefore the ability to take protected industrial action, involves interpreting the wording of the sections strictly without reference to the practical consequences of narrowly construing the operation of the provisions. This is based on the assumption that the Parliament has sufficiently demonstrated its intention through the choice of specific words in the enacted legislation, particularly in the continued use of legislative phrases that have a long-established judicially determined meaning.

The decision that marks the beginning of the specific approach in the present context is the decision by Merkel J at first instance in the Electrolux trial. ${ }^{48}$ Merkel J found against Electrolux regarding the trust fund and shop stewards issues, but accepted that the industrial action taken by the employees was for the purpose of supporting the claims including the bargaining fee claim and, therefore, granted declarations that the industrial action was not protected. In his Honour's view, the bargaining fee claim was not a matter pertaining to the relationship between employers and employees because it established an agency relationship between the

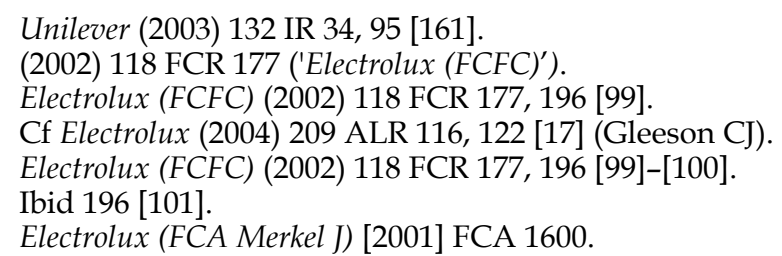


unions and Electrolux. ${ }^{49}$ This analysis was based on the view that a requirement imposed on an employer to establish a pay deduction facility for the payment of the union fees (in this case a bargaining fee payable to the union) was analogous to the pay deduction of union dues, which had been held by the High Court not to pertain to the requisite relationship. ${ }^{50}$ The significance of his Honour's decision lies not in his characterisation of the nature of the bargaining fee, ${ }^{51}$ but rather in his view that the Commission was prevented from certifying an agreement that contained a clause that did not pertain to the requisite relationship.

Merkel J stated that inclusion in the proposed agreement of a term that did not pertain to the requisite relationship, provided that the term was incidental or ancillary to a substantive term that did so pertain, did not prevent the agreement from being certified. ${ }^{52}$ However, if a substantive clause did not pertain to the requisite relationship then the agreement could not be said to be about matters pertaining to the requisite relationship. ${ }^{53}$ This strict interpretation (ie, that the Act requires every substantive aspect of the proposed agreement to pertain to the requisite relationship) has been almost overwhelmingly approved ${ }^{54}$ by the subsequent decisions of the Commission. ${ }^{55}$ One particular decision that deserves comment is the decision in Re Atlas Steels, 56 where the Full Bench of the Commission considered the central issue of whether an agreement that contained terms that did not pertain to the requisite relationship could still be certified. The Full Bench found that the statutory effect of certified agreements (which may be enforceable as awards) meant that the scope of the matters dealt with in agreements, specifically whether the agreement could contain terms that did not pertain to the requisite relationship, should be limited to matters that do so pertain, just as awards must be about matters pertaining to the requisite relationship. ${ }^{57}$ More recently, the decision by Ross VP in Re KL Ballantyne $\mathcal{E}$ National Union Workers (Laverton Site) Agreement $2004^{58}$ found that where a matter had been previously dealt with under an award the matter could be taken to satisfy the test in s 170LI. However, this contention probably does not survive later Full Bench authority, where it was held that the mere existence of an award including the same matter could not necessarily render the clause sufficient to comply with s 170LI..$^{59}$

\footnotetext{
49 Ibid [41].

50 See Rv Portus; Ex parte Australia E New Zealand Banking Group (1972) 127 CLR 353; Re Alcan Australia Ltd; Ex parte Federation of Industrial, Manufacturing and Engineering Employees (1994) 181 CLR 96 ('Re Alcan Australia').

51 This is because bargaining fees are now prohibited by statute: see above $n 33$.

52 Electrolux (FCA Merkel J) [2001] FCA 1600, [50].

53 Ibid [51].

54 The Full Bench in Unilever (2003) 132 IR 34 is the notable exception.

55 See Re Atlas Steels (2002) 114 IR 62; Transport Workers' Union of Australia v National Transport Operations Pty Ltd (2003) 121 IR 339; Re National Union of Workers (2003) 120 IR 438.

56 (2002) 114 IR 62.

57 Re Atlas Steels (2002) 114 IR 62; Transport Workers' Union of Australia v National Transport Operations Pty Ltd (2003) 121 IR 339, 343-4 [23]-[28]; Workplace Relations Act 1996 (Cth) ss 4(1) (definition of industrial dispute), 89A.

58 (unreported, AIRC, Ross VP, PR952656, 22 October 2004) ('Ballantyne').

59 Re Rural City of Murray Bridge Nursing Employees, ANF (Aged Care)-Enterprise Agreement 2004 (2005) 142 IR 289 ('Schefenacker'), 307 [49].
} 


\section{The High Court adopts the specific approach}

Prior to the High Court's decision in Electrolux the divergence in authority outlined above posed significant difficulties for parties involved in negotiations for certified agreements. In particular, the divergence in approaches created uncertainty regarding the proper scope and meaning of s 170LI, particularly:

1. whether all of the substantive provisions in a certified agreement must be 'about matters pertaining to the relationship between employers and employees'; and if not then

2. how a certified agreement may be characterised as being 'about a matter pertaining to the relationship between employers and employees'; and

3. the extent to which an insubstantial clause in a proposed agreement that does not pertain to the requisite relationship may prevent the agreement being certified.

The High Court's decision has resolved some of this uncertainty. The High Court decided by a majority of 6-1 that the bargaining fee clause was not a 'matter pertaining to the relationship between employers and employees'. ${ }^{60}$ The majority overturned the Full Court's decision that protected action may be taken in respect of an agreement that contained terms not pertaining to the relationship between employers and employees. The High Court's decision took the form of a somewhat diverse range of four separate majority opinions, and a dissenting opinion given by Kirby J.

\section{Majority views}

The majority of the High Court agreed with Electrolux that the phrase 'proposed agreement' in the provisions conferring protected status on industrial action must refer to an agreement that is capable of certification under the Act (ie, an agreement that would comply with s 170LI). As the provisions regarding certification require the agreement to be about 'matters pertaining to the relationship between employers and employees', an agreement that contained terms that did not pertain to that relationship must not be an agreement for the purposes of pt VIB, div 2 and, therefore, cannot be certified. A consequence of this is that the agreement must also be incapable of supporting protected industrial action. ${ }^{61}$

Gleeson CJ and McHugh J both found that all of the substantive terms in the agreement must pertain to the employment relationship for a number of reasons. ${ }^{62}$ First, their Honours found that the Act does not allow for the certification of part of an

60 This conclusion was based on previous High Court decisions such as Re Alcan Australia (1994) 181 CLR 96, in which it was decided that the deduction of union dues by the employer was not a matter pertaining to the relationship between employers and employers, but rather between employers and unions.

61 Electrolux (2004) 209 ALR 116, 120-6 [8]-[25] (Gleeson CJ), 141-8 [95]-[122] (McHugh J), 154-9 [149]-[166] (Gummow, Hayne and Heydon JJ), 177-180 [239]-[253] (Callinan J).

62 Callinan J must be taken to have also accepted this point because his Honour stated that he preferred the approach of Merkel J to that of the Full Federal Court: Electrolux (2004) 209 ALR 116, 177-8 [239]. The decision of Gummow, Hayne and Heydon JJ dealt primarily with the construction of $\mathrm{s} 170 \mathrm{ML}$. 
agreement. 63 Secondly, their Honours stated that allowing certification of an agreement that contained substantial matters that did not pertain to the employment relationship would lead to practical difficulties in characterising the agreement. ${ }^{64}$ As Gleeson CJ stated:

All the terms of an agreement ordinarily constitute part of the consideration flowing from one side or the other, and there is no way of knowing whether, or what, the parties would have agreed about the other terms if one term were excluded from the legal operation of the agreement. The argument appears to amount to the proposition that, if an agreement is mainly about the matters referred to in s 170LI, then the fact that it is partly about other matters as well is immaterial. In many cases, it will be impossible to say what an agreement is mainly about, but, in any event, there is no support, either in the text, or in the scheme of Pt VIB, for a conclusion that an agreement that is, in part, about matters other than the matters referred to in s 170LI may be a certified agreement. If it were otherwise, it is difficult to see any logical stopping place short of a proposition that an agreement would fall within the section if it contained even one term about the relevant matters. ${ }^{65}$

The majority judgments also gave extensive consideration to the meaning of s 170ML. The tenor of the majority reasons is to the effect that protected action could not be taken over disputed agreements merely because the parties genuinely believed that the proposed agreement was capable of certification. The position is perhaps best put by Gleeson CJ who stated:

The fact that parties to industrial action may be acting under a mistake of law as to whether a proposed agreement is of that nature is no more relevant to the protection given by s $170 \mathrm{ML}(2)$ than would be the fact that they neither knew nor cared whether the proposed agreement was of that nature. The protection conferred by s $170 \mathrm{ML}(2)$ is attracted by a combination of two circumstances: the purpose of supporting or advancing claims the subject of a proposed agreement; and the nature of the proposed agreement. The kind of proposed agreement being supported is not at large. It is not merely the fact of the proposal and support that is sufficient to gain protection; the nature of that which is proposed is also material. 66

The majority judgments also referred to s 170L which provides that the purpose of pt VIB is to facilitate the making of certified agreements. This was used as the basis for finding that protection for industrial action must therefore be limited under s 170ML to 'action in support of agreements of the nature of the agreements with which pt VIB is concerned, that is to say, agreements of the kind identified in s 170LI. ${ }^{67}$

The majority judgments all include some discussion of the purposes of pt IVB. McHugh J specifically relied on the statutory purposes of the Act to support his

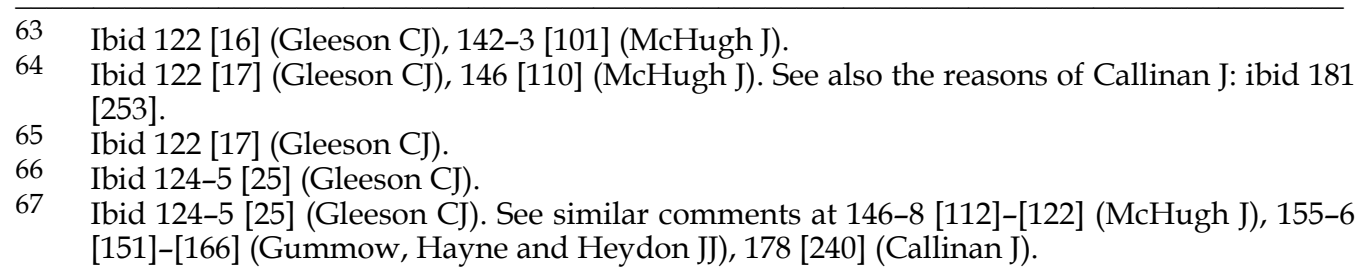


reasoning. ${ }^{68}$ His Honour stated that the reference in $\mathrm{s} 3$ to employers and employees determining their agreement 'whether under the terms of this Act or not' meant that an agreement containing substantial non-pertaining terms could not be certified.69 However, this view belies the range of significant difficulties that collective industrial agreements face outside of the provisions of the Act, which is discussed further below in Part III.

\section{Dissenting view}

Kirby J stressed the importance of interpreting legislation in accordance with its legislative purpose. ${ }^{70}$ His Honour sought to explain the provisions in light of the practical realities of modern industrial relations, specifically noting that pt VIB is based on the assumption that the parties will negotiate between themselves a new collective agreement. ${ }^{71}$ This satisfies the stated statutory purpose of the provisions outlined earlier in this article. If the Act requires negotiation to create a new collective agreement then that negotiation is likely to be characterised by a process of compromise, with each party making claims initially that they intend to water down as part of the bargaining process. ${ }^{72}$ Kirby $\mathrm{J}$ sought to protect the integrity of the bargaining process by ensuring that the protected status given to industrial action allowed the parties to engage in robust bargaining. His Honour stated that a failure to recognise the purpose of protected industrial action in giving parties the opportunity to exercise their economic bargaining power with some reasonable degree of certainty represented an unrealistic view of industrial negotiations. ${ }^{73}$ Furthermore, the consequence of adopting the specific approach to interpretation on the ability to take protected industrial action would create a chilling effect on the bargaining process. ${ }^{74}$

His Honour dismissed the appeal on the basis that the industrial action should have been protected because the bargaining fee clause did not take the proposed agreement outside of the requirement that the agreement be 'about matters pertaining' to the relevant relationship.

\section{E Which approach should prevail?}

In the writer's view, the holistic approach should be preferred to the specific approach on the basis that the former approach is better able to fulfil the objects of the statute. The Acts Interpretation Act 1901 (Cth) s 15AA provides that, where there are various possible interpretations of a federal statute, 'a construction that would promote the purpose or object underlying the Act shall be preferred to a construction that would not promote that purpose or object.' Therefore, the holistic approach should be the preferable method of construction of the Workplace Relations Act 1996 (Cth) because, in the writer's view, the specific approach fails to achieve the statutory purposes of the Act.

Ibid 143-4 [102]-[105].

Ibid 143-4 [105] (McHugh J).

Ibid 162 [182] (Kirby J). This is given statutory force by the Acts Interpretation Act 1901 (Cth) s 15AA.

Ibid 162 [187].

Ibid 163 [187]-[188].

Ibid 163-4 [190].

Ibid 164-5 [192]-[193]. 
The holistic approach requires the parties to a proposed certified agreement to consider whether the agreement as a whole can be said to be 'about matters pertaining to the employment relationship'. It thereby relieves the parties from undertaking the process of legally characterising each clause within their proposed agreement to determine if, according to the prevailing High Court interpretation, each of the clauses is a 'matter pertaining to the relationship between employers and employees' in order to clarify their legal rights, which is what the specific approach requires. Admittedly, it was noted by McHugh J, who found for Electrolux, that the proposed agreement should be characterised as a whole. ${ }^{75}$ However, it is submitted that the practical effect of the majority views, particularly in light of Gleeson CJ's comments extracted above, renders a clause by clause analysis necessary in order to confirm compliance with $\mathrm{s}$ 170LI.

The problem with requiring a clause by clause analysis is that the process of characterisation is by no means simple or straightforward, but rather is a technical and complex assessment based on interpretations of prior authorities. If the purpose of the Act is to provide the optimum level of flexibility in the determination of workplace terms and conditions, ${ }^{76}$ then the Act should be interpreted in a manner that will fulfil those statutory objects. This would mean providing a legal framework that actually facilitates agreement between employers and employees. The specific approach, however, places unreasonable demands on the parties, particularly in a non-union agreement under s 170LK, where the capacity of employees to engage in an accurate legal characterisation of each clause, in the absence of the legal support of a union, must be doubted. The difficulty lies in the requirement to engage in clause by clause analysis rather than a whole of agreement characterisation. It would be far easier for the parties to a certified agreement to examine the instrument as a whole and determine whether that agreement is about matters pertaining to the relevant relationship than to characterise each clause. ${ }^{77}$

As discussed above, the ability to engage in genuine collective bargaining requires some form of counterbalance to the bargaining powers of the parties. In the federal system of collective bargaining the primary counterbalance is the right to take protected industrial action. However, the specific approach restricts this right by narrowing the scope of permissible certified agreements. The holistic approach is designed to facilitate the legitimate use of industrial action as a lawful bargaining tactic within the context of negotiating new certified agreements. The aim of the holistic approach is to provide employers and employees with a high degree of certainty regarding their bargaining powers so that the parties have confidence in asserting their rights. In a system that depends upon enterprise level dispute resolution, the parties

75 Ibid 143 [102]

76 Australian Paper Ltd v Communications, Electrical, Electronic, Energy and Allied Services Union of Australia (1998) 81 IR 15, 18 (North J); cited with approval in the dissenting opinion of Kirby J in Electrolux (2004) 209 ALR 116, 162 [185].

77 It is submitted that the changes brought about by the Workplace Relations Amendment (Work Choices) Act 2005 (Cth) will not remove this difficulty because the new provisions will still require a clause by clause analysis to determine whether any of the clauses falls within the boundaries of 'prohibited content', although it is hoped that the definition of prohibited content under the (as yet unpublished) Workplace Relations Regulations may be more easily applied than the meaning of a 'matter pertaining to the employment relationship'. 
should be able to exercise their bargaining power without facing the threat of penalties being levied for technical errors in legally characterising the proposed agreement, particularly when that process 'may be a matter about which well-informed people have different views'. ${ }^{7}$

The use of the specific approach creates unnecessary uncertainty and complexity in the collective bargaining process. Limiting the power to engage in protected industrial action has the practical effect of distorting the balance of bargaining power between the parties and thereby reducing the flexibility given to the parties to genuinely agree as to what they consider to be the most appropriate form of agreement to regulate their workplace terms and conditions. This result goes against the stated purposes of the Act.

It could be argued that the right to take protected industrial action should be limited because of the negative impact that strikes have on innocent third parties (eg, suppliers and customers). However, the force of this claim must be viewed in light of the fact that the prevalence of industrial action in Australia is declining. ${ }^{79}$ Furthermore, the Act currently provides scope for the Commission to terminate the protected status of industrial action by suspending or terminating the bargaining period operating between the parties. ${ }^{80}$ While it is accepted that these measures cannot currently be initiated by affected third parties, the harm caused to individual third parties should not be a decisive factor in relation to the question of whether industrial action should be protected. ${ }^{81}$ There are a number of reasons to support this, including the prior notice provisions required for taking protected industrial action which allow third parties some time to anticipate disruptions and thereby alleviate their impact. ${ }^{82}$ Furthermore, the most disruptive aspect of industrial action for third parties - that is picketing - is not generally covered by the protections of the Act. ${ }^{83}$ Lastly, as Professors Creighton and Stewart point out, there is ample scope for parties whose interests have been affected by industrial action to apply for an interlocutory injunction, on the basis that the industrial action should not be protected. There are a range of issues that can invalidate protected action, ${ }^{84}$ and the applicant for an interlocutory injunction need only establish a serious question to be tried and that the

78 Electrolux (FCFC) (2002) 118 FCR 177, 195 [93]; Bluescope Steel Ltd v Communications, Electrical, Electronic, Energy, Information, Postal, Plumbing and Allied Services Union of Australia (2005) 137 IR 115 ('Bluescope Steel'), 119-120 [22]; Pacific National (ACT) Pty Limited v Australian Rail, Tram \& Bus Industry Union [2005] FCA 1383, [13].

79 Australian Bureau of Statistics figures indicate that the number of industrial disputes and the number of days lost to industrial disputes has been in decline for the last several years: Industrial Disputes Australia, 17 March 2005, 6321.0.55.001.

80 Workplace Relations Act 1996 (Cth) s 170MW. The Workplace Relations Amendment (Work Choices) Act 2005 (Cth) also contains numerous grounds to suspend or terminate a bargaining period: ss 107G-107J.

81 It should be noted that the Workplace Relations Amendment (Work Choices) Act 2005 (Cth) has introduced the power to suspend or terminate a bargaining period if the industrial action taken during the bargaining period threatens to cause significant harm to a third person: $\mathrm{s}$ 107J.

82 Workplace Relations Act 1996 (Cth) s 170MO.

83 David's Distribution Pty Ltd v National Union of Workers (1999) 91 FCR 463.

84 Creighton and Stewart, above n 9, [18.86]. 
balance of convenience favours granting the injunction. ${ }^{85}$ Therefore it is submitted that third party rights are already adequately protected under the current regime and would not suffer unfair prejudice by the adoption of a broad holistic approach to ss 170LI and 170ML.

\section{PROBLEMS CAUSED BY THE MAJORITY'S RULING IN ELECTROLUX}

In addition to doctrinal problems arising from the majority of the High Court's adoption of the specific approach, there are also substantial practical problems caused by the majority decision in Electrolux. Despite the diversity of opinions contained in the High Court's Electrolux decision, this much seems to be settled:86

- Protected industrial action cannot be undertaken in pursuit of an agreement that contains a substantive clause that does not pertain to the requisite relationship;

- A certified agreement cannot be registered by the Commission if it contains a substantive clause that does not pertain to the requisite relationship; and

- An agreement can still be certified, and protected action can be undertaken in pursuit of the proposed agreement, provided that any terms that do not pertain to the requisite relationship are merely incidental or ancillary to substantive provisions that do so pertain or are mere machinery provisions. ${ }^{87}$

If an agreement cannot be certified where it contains substantive terms that do not meet the requirements of s 170LI, then as the Full Bench of the Commission has noted, 'it would seem to follow that if the Commission purports to certify an agreement containing a provision of that kind the agreement will have no legal effect under the Act. ${ }^{\prime} 88$ Thus, the practical effect of the majority's specific approach to interpreting s 170LI is not only to make the process of certification more complex, to limit the availability of statutory rights to take protected industrial action, but also (and perhaps this is the most concerning aspect of the decision) to leave agreements certified by the Commission lingering under a continuous cloud of uncertainty. The uncertainty arises because if, at any time during the life of the agreement, the parties come before the Commission to resolve a dispute over the application of the agreement using the private arbitration function commonly conferred on the Commission under most

85 Ibid [18.81]. See, eg, John Holland Pty Ltd v Construction, Forestry, Mining \& Energy Union (2005) 144 IR 418.

86 Ballantyne (unreported, AIRC, Ross VP, PR952656, 22 October 2004) [9]; Schefenacker (2005) 142 IR 289, 306-8 [45]-[50].

87 It should be noted that this last point has the potential to be used very broadly, which is why the Full Bench of the Commission in Schefenacker (2005) 142 IR 289, 299-300 [19], said that care should be used when applying the descriptions of incidental and ancillary to particular clauses.

88 Schefenacker (2005) 142 IR 289, 307-8 [50], citing Minister for Immigration and Multicultural Affairs v Bhardwaj (2002) 209 CLR 597, 614-5 [51] (Gleeson CJ), which in turn cites numerous authorities for the proposition that decisions made under a jurisdictional error have no legal effect. 
certified agreements, ${ }^{89}$ one of the parties may well seek to object to the Commission's jurisdiction. An objection to jurisdiction may be made on the basis that the Commission should never have registered the agreement because it contained one or more substantive matters that did not pertain to the requisite relationship; thus the agreement (and hence the power to resolve the dispute) would be a legal nullity. ${ }^{90} \mathrm{~A}$ prerogative writ may well lie against the decision of a Commissioner either to proceed with the private arbitration (in which case prohibition may be sought to prevent the arbitration from proceeding) or to decline to proceed (in which case mandamus may be sought to require the Commissioner to perform the arbitration). An application may also be made to the Federal Court of Australia seeking a declaration to clarify the legal status of the certified agreement. ${ }^{91}$

The continuing uncertainty caused by Electrolux would not be welcomed by either employers or employees and has led to the Full Bench of the Commission recently stating:

Given the difficulties in characterisation which have arisen, and the likelihood that similar difficulties will arise in the future, the Parliament may think it appropriate to give consideration to a legislative amendment which might give a greater degree of certainty to the legal operation of an agreement once it has been certified. ${ }^{92}$

It is unfortunate that this problem was not resolved by the Parliament when it enacted the Workplace Relations Amendment (Agreement Validation) Act 2004 (Cth), as discussed in the next section. ${ }^{93}$

89 Workplace Relations Act 1996 (Cth) ss 170LT(8), 170LW. As to the nature of the Commission's private arbitration function see Carolyn Sutherland, 'By Invitation Only: The Role of the AIRC in Private Arbitration' (2005) 18 Australian Journal of Labour Law 53; Andrew Stewart, 'The AIRC's Evolving Role in Policing Bargaining' (2004) 17 Australian Journal of Labour Law 245.

90 It should be noted that Heerey J recently refused an application for an interlocutory injunction based on the argument that the notice initiating the bargaining period was void because it referred to a matter that did not pertain to the employment relationship: Bluescope Steel (2005) 137 IR 115, 118-120 [15]-[23]. However, in Finance Sector Union of Australia v Commonwealth Bank of Australia [2005] FCA 796, Merkel J found that an agreement that had been certified by the Commission was invalid under the Act because the agreement allowed for operational terms external to the agreement. His Honour found that the Commission's certification was void and that the agreement therefore operated as a common law contract (which his Honour found to be in breach of the freedom of association provisions in Workplace Relations Act 1996 (Cth) pt XA).

91 Judiciary Act 1903 (Cth) s 39B(1A)(c), which speaks of any matters arising under federal law. The High Court has found that the same phrase used in s 76(ii) of the Constitution applies if the rights or duties in question owe their existence to federal law, or depend upon federal law for their enforcement: $R v$ Commonwealth Court of Conciliation and Arbitration; Ex parte Barrett (1945) 70 CLR 141, 154 (Latham CJ). Thus, as the function of the Commission in private arbitration depends upon s 170LW for its enforcement, the jurisdiction of the Federal Court under the Judiciary Act 1903 (Cth) s 39B(1A)(c) should be enlivened.

92 Schefenacker (2005) 142 IR 289, 307-8 [50].

93 The Senate Employment, Workplace Relations and Education Committee, Parliament of Australia, Inquiry into Workplace Relations Amendment (Agreement Validation) Bill (2004) did not address this issue. See further Marilyn Pittard, 'Agreements Straying Beyond 
In addition to this unacceptable state of continuing uncertainty, it is also submitted that the High Court's majority decision raises several further unresolved problems:

1. What is the status of certified agreements already registered and industrial action taken prior to the Electrolux decision?

2. When can a proposed agreement which contains a non-pertaining clause still be registered?

3. Is it possible for the parties to enter into a legally enforceable non-certified agreement in relation to matters that are incapable, in light of the Electrolux decision, of being certified by the Commission?

\section{A The effect of Electrolux on pre-existing agreements and prior industrial action}

The High Court's decision in Electrolux threw into doubt the validity of many existing certified agreements that contained substantive provisions that might not satisfy the Court's interpretation of the requirements of s 170LI. The federal Parliament responded by passing the Workplace Relations Amendment (Agreement Validation) Act 2004 (Cth), which came into effect on 15 December 2004. ${ }^{94}$ This Act amended the Workplace Relations Act 1996 (Cth) so that certified agreements existing, and protected industrial action taken, before 2 September 2004 (the date of the Electrolux decision) would not be invalidated (in the case of an agreement) or rendered unprotected (in the case of industrial action), merely because of the High Court's decision. ${ }^{95}$ The legislation did not, however, deal with agreements or industrial action after that date and, therefore, problems of uncertainty continue to arise in relation to the certification of agreements and the taking of industrial action after 2 September 2004. The problems caused by this continuing uncertainty have been noted above.

\section{B How to characterise a clause as 'incidental, ancillary or mere machinery'}

A proposed certified agreement that contains a clause that does not pertain to the requisite relationship may still be properly registered by the Commission if the clause is: ${ }^{96}$

- ancillary or incidental to a substantive matter that does so pertain to the employment relationship;

- merely a machinery provision; or

- not intended to affect legal rights or impose obligations upon the parties. ${ }^{97}$

Employment Matters: The Impact of the Agreement Validation Matters Legislation' (2005) 18 Australian Journal of Labour Law 71.

94 For a detailed discussion of the validation legislation see Pittard, ibid.

95 Workplace Relations Act 1996 (Cth) ss 170NHA-170NHC. The agreements are validated to the extent that they do not contain matters that do not pertain to the employment relationship.

96 Electrolux (FCA Merkel J) [2001] FCA 1600, [50] (affirmed (2004) 209 ALR 116, 122 [17] (Gleeson CJ), 141 [95]-[96], 143 [103] (McHugh J); not considered by other members of the court); Re Atlas Steels (2002) 114 IR 62, 68 [23]; Unilever (2003) 132 IR 34, 85 [126]; Ballantyne (unreported, AIRC, Ross VP, PR952656, 22 October 2004) [33]-[47]; Schefenacker (2005) 142 IR 289, 307 [47]. See also Victoria v Commonwealth (1996) 187 CLR 416 ('Industrial Relations Act Case' $^{\prime}$, which took a similar position in relation to award matters. 
There has been an extraordinary number of cases in the Commission that have considered this issue, and it is difficult to identify a unifying principle from these decisions. However, something that may be confidently stated is that the characterisation of each clause depends very much upon its particular wording rather than some general notion about matters that have or have not been held to pertain to the employment relationship in the past. Thus, the mere fact that a matter has been previously dealt with by an award will not solely determine that the matter pertains to the employment relationship in the proposed agreement. ${ }^{98}$ Similarly, the mere fact that a proposed clause benefits a union will not prevent the clause, if worded appropriately, from being characterised as a matter pertaining to the employment relationship..$^{9}$

\section{Examples of typical problems}

In order to demonstrate the problems resulting from the Electrolux decision it is appropriate to consider two types of clauses commonly included in certified agreements, namely right of entry clauses and contracting limitation clauses. The point of discussing these two types of clauses is that the legal status of these clauses differs markedly depending upon the wording of the clause and, in some situations, upon which member of the Commission hears the certification application. It should also be noted that the federal government could prohibit these two types of clauses from appearing in workplace agreements following the changes made by the Workplace Relations Amendment (Work Choices) Act 2005 (Cth). 100

\section{Rights of entry}

Clauses that confer rights on union officials to enter workplaces to discuss matters with employees who are members of the union have been a long-time feature of Australian industrial instruments. Indeed, the Act itself provides for limited rights of entry for union officials. ${ }^{101}$ The clause by clause characterisation process required by the majority's decision in Electrolux means that a clause in an agreement that gives a union official a right of entry must be examined to determine whether it is a matter pertaining to the employment relationship. However, parties who wish to include such a clause in a proposed agreement face the difficulty of establishing a clear line of authority in the industrial courts and tribunals as to when a right of entry clause may be characterised as being a matter pertaining to the employment relationship. For example, in Wesfarmers Premier Coal Ltd v Automotive, Food, Metals, Engineering, Printing

97 Electrolux (2004) 209 ALR 116, 122 [17] (Gleeson CJ); Ballantyne (unreported, AIRC, Ross VP, PR952656, 22 October 2004), [48]; Schefenacker (2005) 142 IR 289, 299-300 [19].

98 Schefenacker (2005) 142 IR 289, 307 [49]; cf Ballantyne (unreported, AIRC, Ross VP, PR952656, 22 October 2004).

99 Ballantyne (unreported, AIRC, Ross VP, PR952656, 22 October 2004) [58].

100 If this were to occur, the issue would then focus on whether the term included fits within the scope of the prohibited term. In which case the difficulties discussed below concerning the overly technical nature of the legal requirements relating to agreement would still apply.

101 Workplace Relations Act 1996 (Cth), pt IX. See further William Ford, 'Being There: Changing Union Rights of Entry under Federal Industrial Law' (2000) 13 Australian Journal of Labour Law 1. 
and Kindred Industries Union (No 2), ${ }^{102}$ French J found that limiting the operation of the proposed right of entry clause to situations that would come within the scope of the statutory right in pt IX of the Act, and no more, was not a matter pertaining to the employment relationship. Rather, it could be classed as being ancillary to other provisions in the agreement that were matters pertaining to the employment relationship. ${ }^{103}$ However, in the subsequent Full Bench decision in Re Rural City of Murray Bridge Nursing Employees, ANF (Aged Care)-Enterprise Agreement 2004, 104 ('Schefenacker' as it has been widely referred to by the media), it was held that 'disputes about the operation of the various provisions of Part IX are unlikely to be disputes about matters that pertain to the relevant relationship. ${ }^{105}$

In Ballantyne, Ross VP considered a right of entry clause allowing union officials rights to interview employees. It was held that the clause could be classed as being incidental or ancillary to other clauses in the agreement that were matters pertaining to the employment relationship. This was because the ability to investigate and speak to workers about compliance with the certified agreement allowed for a more effective settlement of the dispute between the workers and the employer and should therefore be permitted. ${ }^{106}$

The subsequent Full Bench decision in Schefenacker provided a reasonably clear test for determining whether a right of entry clause could be said to be a matter pertaining to the employment relationship:

A right of entry which is confined to entry for the purposes of investigating and securing compliance with any relevant award, applicable agreement or other matters that pertain to the relations between employers and employees as such may be included in an agreement. A right of entry which is unconfined is capable of being exercised for purposes extraneous to the employment relationship. A right of entry of the latter kind might be used for the purpose of campaigning for union elections or for the purpose of raising the political awareness of union members in relation to a current political issue. It follows, in our view, that a right of entry confined in the fashion we have indicated may be included in an agreement that satisfies the requirements of s 170LI. ${ }^{107}$

These comments were considered by O'Callaghan SDP, who found that a right of entry clause which provided the power to enter in order to 'interview' workers, without specifying exactly what the workers could be interviewed about, could not be

102 (2004) 138 IR 362 ('Wesfarmers').

103 Wesfarmers (2004) 138 IR 362, 390 [110]-[112]. Cf Country Fire Authority v United Firefighters' Union of Australia (unreported, AIRC, Acton SDP, PR957580, 26 April 2005) where the right of entry provision was drafted as conferring on the Union the right to enter in accordance with the provisions of pt IX, but also added the phrase 'or at times as approved by the CFA for the purposes of conducting legitimate union business'. Acton SDP found that the quoted phrase was substantive in nature and did not pertain to the employment relationship.

104 (2005) 142 IR 289.

105 Schefenacker (2005) 142 IR 289, 330 [116].

106 Ballantyne (unreported, AIRC, Ross VP, PR952656, 22 October 2004) [179]-[214].

107 Schefenacker (2005) 142 IR 289, 331 [119]. 
incidental or ancillary on the basis that the power was capable of being used for purposes outside of the employment relationship. ${ }^{108}$

However, a more recent, but differently constituted Full Bench, took this issue further by finding that a right of entry clause contained in a proposed agreement could be a matter pertaining to the employment relationship provided that the clause was expressly limited by the agreement to 'legitimate purposes'. Such a phrase should be construed as referring to the matters mentioned by the earlier Full Bench in Schefenacker, which are extracted above. ${ }^{109}$

Therefore, one of the practical problems that Electrolux has caused is that it is difficult for the parties to obtain certainty regarding the legal status of their proposed agreement because of the various interpretations of 'matters pertaining to the employment relationship' that are being adopted by each decision. There is simply no clear line of consistent authority, even on something as relatively basic as when a union official may or may not enter the workplace.

\section{Contracting limitations}

Clauses that seek to limit an employer's use of contract labour provide another good example of the difficulties that result from adopting the specific approach. It could be said that the regulation of an employer's use of contract labour is a borderline issue which could in some circumstances be found to be a matter not pertaining to the employment relationship, while in other contexts the matter may pertain to the employment relationship. Thus, it has been held that a blanket limitation on the use of contract labour is not a matter pertaining to the employment relationship. 110 While in other cases, it has been held that regulating the use of contract labour may be a matter pertaining to the employment relationship if the manner of regulation has a direct connection with the employment security of the workers covered by the agreement. ${ }^{111}$

The difference in outcome is directly determined by the different wording of the proposed agreement and the linking of the matter to the workplace terms and conditions of the employees covered by the agreement, for example by requiring that contract workers are engaged on terms and conditions no less favourable than offered by the proposed agreement. However, an examination of the cases on this issue reveals

108 Re South Pacific Tyres Retreading (Windsor Gardens) Enterprise Agreement 2004 (unreported, AIRC, O'Callaghan SDP, PR957737, 3 May 2005). See also Re CSR Ltd Mawson Lakes South Australia Enterprise Agreement 2004 (unreported, AIRC, O'Callaghan SDP, PR957484, 19 April 2005) where the clause prevented the agreement from being certified because it did not specifically limit the right of entry to enforcing the agreement's grievance procedures.

109 Metropolitan Fire and Emergency Services Board v United Firefighters' Union of Australia (AIRC, Ross VP, Hamilton DP and Gay C, PR957547, 22 April 2005, unreported) [26].

$110 R$ v Commonwealth Industrial Court Judges; Ex parte Cocks (1968) 121 CLR 313; Transport Workers' Union of Australia v National Transport Operations Pty Ltd (2003) 121 IR 339; Construction, Forestry, Mining E Energy Union v Mount Thorley Operations Pty Ltd (1997) 79 FCR 96; Wesfarmers (2004) 138 IR 362.

111 R v Moore; Ex parte Federated Miscellaneous Workers Union of Australia (1978) 140 CLR 470, 472-3 (Gibbs J); Ballantyne (unreported, AIRC, Ross VP, PR952656, 22 October 2004) [113]; Schefenacker (2005) 142 IR 289, 320-1 [83]. 
that this is a very fine and often difficult distinction to make, allowing the parties to easily fall into error and thereby prevent the agreement from being certified.

In Schefenacker, the Full Bench found that a clause which directed the employer to instruct labour hire agencies to pay their workers under the same wage rates as applied under the certified agreement was a matter pertaining to the employment relationship, or was at least an aspirational clause that did not confer a substantive obligation on the employer and, therefore, did not prevent the agreement from being certified. ${ }^{112}$ Whereas in another case, a clause which provided that '[c]asual employees engaged by a Labour Hire Company working in a position covered under this agreement shall be employed on the same wages and conditions as applies to a [casual engaged directly by the employer]' was found to be an attempt to make a non-party to the agreement (ie, the labour hire company) bound by the agreement and, therefore, was not a matter pertaining to the employment relationship. ${ }^{113}$ The most recent line of decisions has determined that any determination of the circumstances in which contractors may be utilised by the employer (for example, 'contractors may only be used to cover peak demands for labour'), even where the purpose of such prescription is to enhance the security of employment for the workers covered by the agreement, will prevent the agreement from being certified because it contains a matter that does not pertain to the employment relationship. ${ }^{114}$ The clear difficulty involved in this area is the fact that both clauses attempt to achieve the same goal, that is, regulating the cost of labour so that the employment security of the workers covered by the proposed agreement is not jeopardised. However, the differences in the wordings of the clauses can render the entire agreement incapable of certification and render industrial action taken in support of the clause unprotected. As one commentator has recently noted, the determination of whether an agreement complies with the Act largely depends on how the clauses are drafted, rather than the nature of the subject matter covered by the clauses. ${ }^{115}$

One thing is made demonstrably clear by the cases considered above in relation to rights of entry and contracting clauses, and that is that parties negotiating certified agreements are forced, because of the specific approach endorsed by the majority in Electrolux, to walk a very fine and often shifting line between clauses whose wording will satisfy the requirements of s 170LI and those that will not. Unfortunately for the parties the legal position only becomes clearer once the Commission actually considers

112 Schefenacker (2005) 142 IR 289, 320-1 [83]. This decision was applied by the subsequent Full Bench in Re Transport Workers' Union of Australia and Australian Air Express (2005) 142 IR 409

113 Re Inghams Enterprises (Mile End Feedmill) Certified Agreement 2002 (unreported, AIRC, O'Callaghan SDP, PR956998, 5 April 2005).

114 This follows the authority in R v Commonwealth Industrial Court Judges; Ex parte Cocks (1968) 121 CLR 313. The most recent Full Bench decision which supports this point is Re National Union of Workers (unreported, AIRC, Giudice P, McCarthy DP and Mansfield C, PR962259, 9 September 2005), which has been applied by O'Callaghan SDP in several subsequent decisions (see, eg, Australian Workers' Union v Australian Municipal, Administrative, Clerical and Services Union (unreported, AIRC, O'Callaghan SDP, PR964439, 31 October 2005)).

115 Kelly Godfrey, 'To Pertain or not to Pertain to the Employment Relationship: that is the Question' (2005) 33 Australian Business Law Review 55, 55. 
the agreement for certification. ${ }^{116}$ It would appear that the majority's decision in Electrolux has done little more than ensure the need for extensive litigation to determine what wording is more likely to be accepted in relation to each type of clause. ${ }^{117}$

\section{Identifying incidental, ancillary or machinery provisions}

It is submitted that the following comments provide a useful framework for assisting with the characterisation of a clause as incidental or ancillary to a substantive clause that does pertain to the requisite relationship:

[A] clause in an agreement can properly be regarded as incidental to another if it has a rational and natural tendency to affect the operation of that other clause in a manner that is direct as opposed to consequential or remote. 118

A clause in a proposed agreement is unlikely to be characterised as incidental, ancillary or machinery in nature where it contains a high level of prescribed conduct so that the clause can be said to stand adequately on its own. ${ }^{119}$ On this basis there would appear to be little scope for parties negotiating a new certified agreement to attempt to include any significant matters that are at risk of not pertaining to the requisite relationship in the new agreement, in the hope that the clause will be accepted by the Commission as incidental, ancillary or merely machinery in nature. However, this point is far from clear as Ross VP has recently given the term 'ancillary' a very broad meaning. In Ballantyne, Ross VP noted in obiter comments that 'ancillary' could refer to 'a means of making a substantive provision effective'. ${ }^{120}$ Furthermore, Ross VP rejected a submission from the Australian Chamber of Commerce and Industry that any ancillary or incidental provision needs to be linked directly to a substantive provision that does pertain to the employment relationship. ${ }^{121}$ It is submitted that this view may not survive more recent authority. ${ }^{122}$

This then leaves parties negotiating a new certified agreement with the option of pursuing the non-pertaining matters in a common law contract. However, it is submitted that this alternative is fraught with problems of legal principle which may, in many workplace situations, be insurmountable, leaving the parties with no legal method of regulating and enforcing certain aspects of their collective relationship. This

116 The Workplace Relations Amendment (Work Choices) Act 2005 (Cth) will exacerbate this problem because the Commission will no longer vet agreements, with agreements taking effect once they are lodged with the Office of the Employment Advocate. However, the uncertainty surrounding the agreements as discussed in this article will continue because of the possibility of the agreements containing 'prohibited content'. This is discussed in the Postscript below.

117 Godfrey, above $\mathrm{n} 115,61$.

118 Re National Standards Commission Certified Agreement 2003-2004 (2003) 125 IR 350, 353-4 [13]. See also NSW Teachers Credit Union Ltd v FSU (unreported, AIRC, Richards C, PR936565, 22 August 2003) ('NSW Teachers Credit Union').

119 NSW Teachers Credit Union (unreported, AIRC, Richards C, PR936565, 22 August 2003); Wesfarmers (2004) 138 IR 362, 390 [109].

120 Ballantyne (unreported, AIRC, Ross VP, PR952656, 22 October 2004) [47].

121 Ibid [70]-[74].

122 Schefenacker (2005) 142 IR 289, 299-300 [19]; Wesfarmers (2004) 138 IR 362, 390 [109]. 
hardly seems to conform to the stated purpose of the Act to provide flexibility in entering into the most appropriate form of industrial agreement. ${ }^{123}$

\section{Is there scope for unregistered agreements?}

The comment has been made in several recent cases that where a clause in a proposed agreement cannot be included in the agreement submitted to the Commission for registration, then the parties should deal with the matter according to the general law. ${ }^{124}$ However, the enforceability of unregistered collective agreements is an area of industrial law plagued by uncertainty. ${ }^{125}$ The range of difficulties that arise in relation to enforcing unregistered agreements as legally binding contracts relate to problems with the legal status and powers of trade unions, and also to problems of uncertainty, lack of contractual intention and absence of consideration.

Many of the difficulties with the enforceability of unregistered agreements concern the uncertainty regarding the proper legal status of registered trade unions. For example, if a trade union is a party principal to a certified agreement under s 170LJ, the Act provides a framework where all of the potentially affected workers are given an opportunity to vote on the proposed collective agreement, and (provided the vote achieves the required majority) all of the current and future workers are bound. ${ }^{126}$ The great benefit of registration and enforcement of collective agreements under the Act is the ability to achieve uniformity and consistency through binding dissenting workers. The same cannot be said of unregistered agreements between employers and unions at common law. At common law, although a registered union is a body corporate with the power to enter into contracts in its own right, ${ }^{127}$ the powers of trade unions are limited by the scope of their internal rules, ${ }^{128}$ which gives rise to doubts that trade unions have the power to enter into valid contracts outside of the scope and purposes of the Act. 129

Aside from problems concerning the capacity of trade unions to enter into industrial contracts outside of the Act, unregistered agreements are also problematic because of the union's potential inability to enforce compliance with the terms of the contract on the entire workforce. ${ }^{130}$ The fundamental problem is that the union cannot

123 One counter argument to this, although outside the scope of this article, is that it is perfectly appropriate that the workplace relationship not be wholly regulated by laws, but rather by a mixture of laws and non-legal mechanisms: Davies and Freedland, above n 22, 161.

Electrolux (2004) 209 ALR 116, 143 [103] (McHugh J); 155-6 [154] (Gummow, Hayne and Heydon JJ); Electrolux (FCA Merkel J) [2001] FCA 1600, [50]; Construction, Forestry, Mining and Energy Union v AIRC (2001) 203 CLR 645, 658 [34].

125 Gregory v Philip Morris Ltd (1987) 77 ALR 79, 93; ACTEW Corporation Ltd v Pangallo (2002) 127 FCR 1, 17-8 [33] (Whitlam and Gyles JJ); James Macken et al, The Law of Employment (5 ${ }^{\text {th }}$ ed, 2002) 586-8; Creighton and Stewart, above n 9, ch 7.

126 Workplace Relations Act 1996 (Cth) ss 170LE, 170M.

127 Workplace Relations Act 1996 (Cth) Sch 1B s 27.

128 R v Bowen; Ex parte Amalgamated Metal Workers \& Shipwrights' Union (1979) 144 CLR 462.

129 See Breen Creighton, William Ford and Richard Mitchell, Labour Law: Text and Materials (2nd ed, 1993) [25.27]-[25.37].

130 Ryan $v$ Textile Clothing E Footwear Union of Australia [1996] 2 VR 235, 248-9 (Brooking JA) ('Ryan'). 
be said to be the authorised agent for non-members ${ }^{131}$ and, therefore, does not have the power to bind non-members to their unregistered agreements made with the employer. The historically low levels of current union membership in the private sector mean that it is likely that in many workplaces a union will not represent even a majority of the workforce. Employers are unlikely to support an agreement that does not apply equally to their entire workforce or, at least, equally to certain distinct sections of the workforce. It is more likely that such problems will result in employers refusing to enter into unregistered agreements unless the workers unanimously support the agreement, thereby requiring a contract not with the union but with the individual workers. It would be highly unlikely that the unregistered collective agreement could be simply incorporated into each individual worker's contract of employment. ${ }^{132}$ Therefore, the workers would need to agree as a group to enter into the contract with the employer which would require uniformity of opinion in the workforce that is simply unrealistic. Even assuming that the workers could unanimously agree on a contract with their employer, they may feel uneasy about entering into a contract with their employer personally, particularly if the agreement imposes mutual obligations on the parties. If the parties attempt to draft the agreement in very broad terms so that the agreement can achieve unanimous support, the agreement risks becoming void for uncertainty or lacking the intention to create legal relations. ${ }^{133}$

The changing body of persons that make up the workforce for a particular employer poses equally difficult problems for making unregistered agreements common law contracts. ${ }^{134}$ Suppose that an unregistered agreement were in place with all of the workers of a particular employer, how would changes be made to the contract? Amendments to the contract may be needed as each employee leaves the employer's workforce and as each new employee enters the workplace, which would impose a significant administrative burden on the employer. It might be argued that the employer could be bound by the contract to only offer new employment on the condition that each new employee agrees to the terms of the contract, although this raises the possibility of the contract being an unreasonable restraint of trade. ${ }^{135}$

It may be thought that this problem could be resolved by drafting the contract in the broadest terms possible so that such changes are unnecessary. However, a lack of particularity in a contract would be likely to render the contract, or at least parts of it, void for uncertainty. It may well be that some uncertifiable terms (particularly those that express vague intentions or aspirations of the parties) are inherently uncertain and

131 Indeed, there may even be problems with treating a union as an agent of its members in some cases: see Ryan [1996] 2 VR 235, 238-9 (Brooking JA).

132 Byrne v Australian Airlines Ltd (1995) 185 CLR 410.

133 See Creighton, Ford and Mitchell, above n 129, [25.39]-[25.45]; Ryan [1996] 2 VR 235; Ford Motor Co Ltd v Amalgamated Union of Engineering \& Foundry Workers [1969] 2 QB 303.

134 Ryan [1996] 2 VR 235, 238-9 (Brooking JA); United Firefighters' Union of Australia v Metropolitan Fire and Emergency Services Board (2003) 198 ALR 466, 484-8 [64]-[80] (where the agreement was not a contract because of uncertainty regarding who would be bound in the future).

135 See Creighton, Ford and Mitchell, above n 129, [25.33]-[25.35]; Dyson Heydon, The Restraint of Trade Doctrine (2nd ed, 1999) 208. 
could not be included in any enforceable contract. ${ }^{136}$ However, there is some support for the view that broad aspirational terms that are not intended to create legally binding obligations may be included in a valid certified agreement. ${ }^{137}$

There is also the further problem of agreement fragmentation, especially in light of the furore surrounding the Emwest litigation. ${ }^{138}$ The Full Court of the Federal Court's decision in Emwest affirmed the earlier trial decision by Kenny J, which provided that where a certified agreement did not comprehensively cover all issues that may arise between the employer and its workers, the workers could take protected industrial action in support of claims that were not covered by the agreement (in that case redundancy benefits). This has led to agreements now commonly including whole of agreement clauses to prevent any further issues outside of the scope of the agreement allowing protected action to be taken. ${ }^{139}$ Herein lies the practical difficulty with the Electrolux decision. The Electrolux decision means that registered agreements can only deal with certain matters, which may result in impermissible matters continuing to cause industrial disharmony, although the threat of lawful industrial action is reduced by the narrow interpretation of protected action used by the Court. ${ }^{140}$ One benefit of registered industrial agreements is that they provide certainty for employers who can rely on the industrial peace that should be obtained during the term of the registered agreement. Therefore, if the parties to a certified agreement wish to make an unregistered agreement in resolution of a dispute over matters that cannot be included in the certified agreement because of the Electrolux ruling (for example broad based contracting bans), they may face problems because the certified agreement will need to include a whole of agreement clause to avoid the Emwest problem, which would thereby render the unregistered contract unenforceable. ${ }^{141}$

Perhaps a resolution could be to draft the whole of agreement clause so as to limit its operation to matters pertaining to the requisite relationship. It is imperative, however, that the unregistered agreement not attempt to alter the terms of the certified agreement. Nor could it attempt to impose further burdens on the parties following the recent decision in McLennan v Surveillance Australia Pty Ltd, ${ }^{142}$ where Black CJ and Moore J found that an attempt to vary an AWA by way of an unregistered agreement had no legal effect. This was because their Honours held that the legislature could not

136 See Creighton, Ford and Mitchell, above n 129 [25.39]; Davies and Freedland, above n 22, 160.

137 Electrolux (2004) 209 ALR 116, 122 [17] (Gleeson CJ); Ballantyne (unreported, AIRC, Ross VP, PR952656, 22 October 2004) [48]; Schefenacker (2005) 142 IR 289, 299-300 [19].

138 Emwest Products Pty Ltd $v$ Automotive, Food, Metals, Engineering, Printing and Kindred Industries Union (2002) 117 FCR 588 (affirmed Australian Industry Group v Automotive, Food, Metals, Engineering, Printing and Kindred Industries Union (2003) 130 FCR 524).

139 See for example, National Fleet Network Pty Ltd $v$ Automotive, Food, Metals, Engineering, Printing and Kindred Industries Union (2005) 143 IR 45.

140 Peter Punch, 'Electrolux - the Implications', Industrial Law News (Issue 9, 2004) 3.

141 It should be noted that the Workplace Relations Amendment (Work Choices) Act 2005 (Cth) inserts a new s 110 which provides that industrial action may not be taken before the nominal expiry date of the agreement 'whether or not that industrial action relates to a matter dealt with in the agreement'. The Work Choices amendments also make a similar provision for AWAs: s 110A.

142 (2005) 139 IR 209. 
have intended to create a system whereby parties could freely bargain to reach an agreement governing the matters pertaining to their employment relationship, and in so doing remove any award or certified agreement protection,, 143 but also allow that bargain to be altered by an unregulated and unregistered collateral contract. ${ }^{144}$ The provisions governing the effect and variation of AWAs considered by the Full Court of the Federal Court are, for present purposes, identical to the provisions that apply in relation to certified agreements, which means there is no reason to limit the reasoning in McLennan from operating in relation to certified agreements. Furthermore, in the recent decision in Finance Sector Union v Commonwealth Bank of Australia, ${ }^{145}$ Merkel J held that an agreement certified by the Commission which contained a clause allowing the agreement to be added to by a collateral contract resulted in a failure to provide all of the terms of the agreement for certification, which rendered the entire agreement incapable of certification. Thus, the proposition that any non-pertaining matter that is excluded from the certified agreement because of the Electrolux case can simply be included in a common law contract must be doubted. ${ }^{146}$

Finally, unregistered agreements may be unenforceable because they lack consideration, although this may be overcome through the use of a deed. There also is authority for the view that the peace obligation given by the workers or the union will constitute sufficient consideration to support the contract. 147

Therefore, it can be said that there seems to be no easy way for parties to a certified agreement to create an enforceable collective common law agreement dealing with matters that do not comply with the Electrolux interpretation of s 170LI without giving rise to a number of legal uncertainties.

\section{CONCLUSION}

It is submitted that the majority in Electrolux took an unduly narrow view of what may constitute an 'agreement' under pt VIB, div 2 of the Act, without sufficient regard being paid to the practical difficulties that are likely to be caused by the decision. The immediate effect is that employees and, if applicable, their unions, must engage in a time consuming, legal analysis of each clause in any proposed agreement to determine whether all of the substantive clauses may be characterised as pertaining to the requisite relationship. In situations where the parties can afford proper legal advice, this process might not be too difficult. However, with union membership at historically low levels of less than 20 per cent in the private sector, for groups of

143 Workplace Relations Act 1996 (Cth) ss 170LZ, 170VR.

144 McLennan v Surveillance Australia Pty Ltd (2005) 139 IR 209 ('McLennan'), 228 [47]-[48] (Black CJ and Moore J).

145 [2005] FCA 796.

146 It should be noted that in Finance Sector Union $v$ Commonwealth Bank of Australia [2005] FCA 796, Merkel J did find that the void certified agreement operated as a common law contract. However, it is submitted that this does not detract from the writer's contention that matters which could not be included in a certified agreement could easily form an enforceable common law contract. Difficulties of uncertainty and intention may be reduced when viewing the agreement as a whole and, thus, the entire agreement may well be more easily enforced as a contract than specific elements of that agreement in isolation. 
unrepresented employees or small businesses with no experience in industrial law, this will prove virtually impossible or at best very costly. ${ }^{148}$ For parties without the sufficient resources and expertise to effectively determine the legal character of particular clauses, the threat of penalties and common law action will hang like the sword of Damocles above their heads. The result will be that any clauses that have any element of doubt regarding whether they pertain to the requisite relationship will be dropped from the agreement, otherwise the parties will be prevented from taking industrial action altogether. This situation cannot be said to be the preferable construction of the Act, given that it does not seem to achieve the statutory purposes.

It is submitted that the holistic approach to interpreting the requirements of pt VIB offers the best method of maintaining regulatory neutrality between the parties involved in industrial negotiations. The narrow interpretation adopted by the 'specific approach' discussed above increases the complexity of federal collective bargaining 149 and discourages the use of otherwise legitimate bargaining techniques to genuinely settle actual or potential industrial disputes by dealing with all of the issues deemed important by the parties. The right to engage in protected industrial action underpins the integrity of the system of collective bargaining by evening up the bargaining power of the parties. ${ }^{150}$ A restriction of the right to engage in protected industrial action only increases the bargaining power of the economically stronger bargaining party, and thereby further skews the likely outcomes of the bargaining to that party's favour. This seems inconsistent in a workplace bargaining system that has the goal of leaving the determination of workplace terms and conditions to employers and employees, subject to the minimum award safety net. The Electrolux case may well represent a 'bad decision made by a bad court',151 but the decision is here to stay and, therefore, Parliament should turn its attention to resolving some of the problems that have been created by the decision.

\section{POSTSCRIPT}

Since this article was written, the federal Parliament passed the Workplace Relations Amendment (Work Choices) Act 2005 (Cth), which introduced significant amendments to the Workplace Relations Act 1996 (Cth). The Work Choices amendments affect the provisions discussed in this article in two ways:

First, the Work Choices amendments repealed pt VIB of the Workplace Relations Act 1996 (Cth) and introduce a new pt VB, Workplace Agreements. However, many of the current features under pt VIB have been retained under the new pt VB, although with different numbering. Reference has already been made to the new provisions in the footnotes throughout this article.

Secondly, the Work Choices amendments removed the requirement of certification for workplace agreements. Under the new pt VB, individual and collective agreements will not require the certification of the Commission. Rather, the agreements will take

\footnotetext{
148 Andrew Stewart, 'Electrolux in the High Court: Strict Interpretation, Uncertain Results', Industrial Law News (Issue 9, 2004) 1.

149 Punch, above $\mathrm{n} 140$.

150 Anderman, above n 23, 73.

151 As cited in Godfrey, above n 115, 55
} 
affect after being lodged with the Office of the Employment Advocate. However, while this may seem to overcome many of the problems discussed above, it is submitted that the Work Choices amendments will not reduce the uncertainty caused by the Electrolux decision. The reason for this is that the new procedure of lodging agreements is not conclusive of the agreements' legal force under the Act. The new provisions introduce the concept of 'prohibited content'. The new law provides for the invalidation of an agreement to the extent that it contains prohibited content, and penalties (albeit in limited circumstances) for employers who lodge an agreement that contains prohibited content. Clearly, the new provisions shift the responsibility of vetting the agreements from the Commission over to the parties, which is consistent with the effect of the Electrolux case as discussed above.

The difficulty created by the Work Choices amendments is that 'prohibited conduct' is not set out in the Act, but rather will be determined by regulation. There has been extensive discussion about what might be prohibited content, and it would seem that bans on contracting will certainly be included in the regulations as prohibited content, although as shown above, bans on contracting (as opposed to mere regulation of contracting to secure wage parity between workers covered by the agreement and contractors) are already classed as being outside of the lawful contents of agreements. Furthermore, protected industrial action cannot be undertaken in respect of claims to include prohibited content in an agreement. ${ }^{152}$

Therefore, it is submitted that the problems generated by the Electrolux decision are by no means solved by the Work Choices amendments. On the contrary, the meaning of prohibited content in the new regulations is likely to be vigorously tested by unions and employer groups, leading to more litigation and increasing delays and uncertainty in negotiating workplace agreements.

152 See the new Workplace Relations Act 1996 (Cth) s 108A. 